\title{
The Generation of Iron and the Final Stumbling Block: The Present Time in Hesiod's Works and Days 106-201 and Barnabas 4
}

\author{
Kylie Crabbe
}

The four (or five) kingdom paradigm is a way of playing with time. It offers a set of symbols for structuring history, explaining the past and current circumstances, as well as the future, while situating the reader's time within an overarching pattern. It is arguably so effective a tool for this that it is found in texts that are diverse in genre and in their literary and cultural communities, as writers constantly recalibrate the timeline for each new "present" time.

In what follows I consider texts that are, in many ways, very different from one another, in order to explore elements of this structuring of history and, in particular, how it shapes various authors' portraits of their own time. Part one considers an exceptionally early text, Hesiod's account of generations in Works and Days ${ }_{106-201,}{ }^{1}$ and some common themes taken up in later (Augustan period) Latin texts. Part two turns to the Epistle of Barnabas 4 as a recalibration of Daniel 7. In different ways, I suggest, these texts use the paradigm to interpret significant features of the present time by placing it within a larger framework.

\subsection{Hesiod's Works and Days}

Hesiod's Greek-language didactic poem Works and Days addresses Perses as the object of the poem's instruction. ${ }^{2}$ The poem comprises an assortment of

1 West calculates the possible dates of Hesiod's birth as between 750 and 720 BCE, with the writing of Works and Days shortly following the death of his father, most likely before 690 (M. L. West, Hesiod: Works and Days, [Oxford: Oxford University Press, 1978], 30-33).

2 On intertextual links between this poem and Hesiod's other works, see Jenny Strauss Clay, Hesiod's Cosmos (Cambridge: Cambridge University Press, 2003), 5-10. 
materials on diverse themes. ${ }^{3}$ The myth of five generations ${ }^{4}$ comes early on, as the second of two stories about how evil and vice entered human experience. The first story (lines 47-105) is that of Prometheus and Pandora, in which evil and suffering are unleashed through the opening of the lidded storage jar (94-95). ${ }^{5}$ It concludes with an explanation that "countless other miseries roam among humankind; for the earth is full of evils" (100-1), ${ }^{6}$ and the summary statement, "Thus it is not possible in any way to evade the mind of Zeus" (105). The myth of generations (106-201) is introduced in this context as another

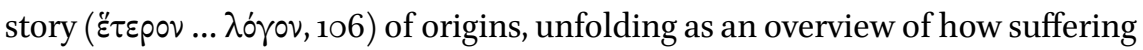
and vice have developed over the generations. ${ }^{7}$

Hesiod describes four metallic generations (gold, silver, bronze, and iron) with a generation of heroes inserted between the bronze and iron ones. There is a general consensus that the sequence of the four metals is not original to Hesiod or even of Greek origin; most suggest it derives from ancient Near Eastern traditions, and that Hesiod added the heroes generation into the paradigm. ${ }^{8}$ Although various ancient Near Eastern texts also portray some form of the kingdom paradigm, including examples involving the metals, the best explanation is of a shared earlier source; there is no extant text that might

3 Clay, Hesiod's Cosmos, 31-32. West notes that the poem draws heavily on wisdom literature (West, Hesiod: Works and Days, 22-25).

4 There is some contention about whether Hesiod describes five or six generations. I argue below that there are five. Throughout this essay I translate $\gamma^{\prime} v o \varsigma$ as generation, not "race." Given the contemporary recognition of issues about race as a construct, and the sense that this does not in any case perfectly capture the Greek, I have avoided the term; where it is used in citations of the primary text I have adapted the citation by using the Greek. While recognizing that "generation" is also not a perfect English translation, this choice is also supported

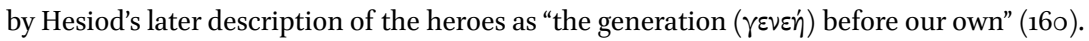

5 The name is literally all-gifts, because she was created through the contributions of "all who live upon Olympus" (8o-82).

6 Unless otherwise specified, throughout I use the LCL translations of the key texts, except Daniel, for which I use the NRSV. In this citation the LCL translation has been modified for inclusive language.

7 The introduction to the myth of generations (106-8) implies it is intended to complement the Prometheus and Pandora story (A. S. Brown, "From the Golden Age to the Isles of the Blest," Mnemosyne 51 [1998]: 385-410, esp. 387).

8 Clay, Hesiod's Cosmos, 81. Haijo Jan Westra and Milo Nikolic, "The Logic of the Myth of the Ages in Hesiod's Works and Days," Mouseion 6.3 (2006): 313. Most suggest the myth is not in keeping with other ideas from Hesiod, while ancient Near Eastern versions of the myth do not incorporate Greek ideas (which might be expected if they were drawing on Hesiod's version). For detailed discussion of possible sources, as well as plausible explanations for the transfer of these ideas into Greece at this time, see West, Hesiod: Works and Days, 172-77. 
be considered Hesiod's source. ${ }^{9}$ Despite the eastern elements, Hesiod's version incorporates numerous Greek features in the descriptions of each of the generations. A. S. Brown speculates that Hesiod's audience would likely already be familiar with a version of the myth involving the four metals and that they would find the adaptation of the underlying myth exotic and enticing, while also recognizing the Greek motifs with which it is merged. ${ }^{10}$

\subsubsection{Hesiod's Version of the Five Generations and Its Key Themes}

Hesiod sets out the generations in descriptions that encourage comparison of their key attributes, including similarities in the descriptions of each generation's creation, behavior, food sources, and ultimate end. He informs Perses that the golden generation were the first human beings created by the gods on Olympus, during Cronos's divine reign. ${ }^{11}$ They lived a life, like the gods themselves, "entirely apart from toil and distress" (112-13), and devoid of evil. Their lives were marked by wealth and blessing and their deaths were simply like falling asleep, following which they have become "fine spirits upon the earth, guardians of mortal human beings," walking the earth invisibly to observe "judgements and cruel deeds" and to give wealth (122-26). ${ }^{12}$

By contrast, the second generation made by those on Olympus-silverwere "much worse" and "like the golden one neither in body nor in mind" (129). They remained in foolish infancy for a hundred years, only to die shortly after reaching puberty as a result of their folly, engaging in hubris against one another and irreverence to the gods. After their time they took up residence under the earth. Despite all this, and although they attracted Zeus's anger, they still enjoy blessing, "in second place, but all the same honor attends upon these as well" (142).

The third generation are worse still. This bronze generation, again noted for its utter difference from the preceding one, is made by Zeus alone, from ash trees. This generation are "terrible and strong" (145), massive in stature and interested only in war and violence, with weapons (and houses) of bronze. The "frightful" generation are ultimately "overpowered by one another's hands" and descend "nameless into the dank house of chilly Hades" (152-55).

9 John J. Collins, A Commentary on the Book of Daniel, Hermeneia (Minneapolis: Fortress, 1993), 164-65. See also West, Hesiod: Works and Days, 172-77.

10 Brown, "From the Golden Age," 387.

11 Although the metals are often thought to represent declining value, West points out that iron was also expensive (West, Hesiod: Works and Days, 173), and Brown outlines numerous other connotations of metals, including gold's incorruptibility and association with the gods (Brown, "From the Golden Age," 392-95).

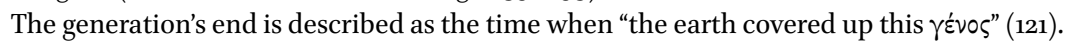


At this point in the unfolding account, things change. Hesiod says that Zeus again made another generation, but this one is "more just and superior" (158), indeed they are "the révos of men-heroes, who are called demigods" (159-6o). For the first time Hesiod situates the story in relation to his (and his audience's) own time, saying that this is "the generation before our own upon the boundless earth" (16o). Hesiod refers to great battles of the Greek past, in Thebes and Troy. And, although they lead to the heroes' death, these battles are nobler than the self-destructive violence of the bronze generation. Zeus settles them in the utopian "Islands of the Blessed" at the limits of the earth, where they enjoy the land's extraordinary fecund provisions as "happy heroes" (168-73).

With this positive situation for the heroes still fresh in the reader's mind, Hesiod introduces the remaining generation ominously: "If only then I did not have to live among the fifth men ( $\dot{\alpha} \nu \delta \rho \alpha \sigma v)$ but could have either died first or been born afterward! For now the révos is indeed one of iron" (174-76). This generation of iron-an inversion of the golden generation - "will not cease from toil and distress by day, nor from being worn out by suffering at night, and the gods will give them grievous cares" (176-78). Although they will enjoy some mix of good things, Zeus will destroy them also "when at birth the hair on their temples will be quite grey" (181). Such a collapse of the natural order will also be evident in the breakdown of concord between family, guests and hosts, and friends, including dishonor towards ageing parents with no regard for divine retribution. They will resort to violence and dishonesty, and be marked by envy. At such a time, "Reverence" and "Indignation" will flee to Olympus, while "Baleful pains will be left for mortal human beings, and there will be no safeguard against evil" (200-1). These are the bleak, concluding words of Hesiod's account of the myth. ${ }^{13}$

Hesiod thus uses the paradigm to structure Greek history from the mythical past and to place his own time in that context. In doing so, he weaves in numerous tropes of decline which both rely upon and highlight the temporality of the paradigm. Structured comparisons between the generations draw out the progressive elements of decline: hubris and impiety develop over the silver and bronze generations and take up new forms in the iron generation. While death begins for the members of the golden generation as a process simply like falling asleep, later humans bring about their own destruction, whether scurrilously as in the case of the violence between members of the

13 Hesiod then offers further exhortation to Perses, in the form of an animal fable that follows the section on the myth of generations. 
bronze generation, or through war (presented more positively) in the generation of heroes. ${ }^{14}$ From a life of ease for the golden generation, the need for labor emerges as some kind of response to, or result of, the emerging vice and impiety. ${ }^{15}$ In somewhat disturbing images involving distortions of infancy, the silver generation exhibits an extended infancy and never reaches beyond puberty while, in events still to unfold in the iron generation, both immaturity and decay will appear together in infants with grey hair. ${ }^{16}$

Thus, there are numerous tropes across the generations which highlight decline. But Hesiod does not use the paradigm to indicate simply a continuous downward path, as presented over the four kingdoms by, for instance, Ovid or Daniel. The generation of heroes in the account as Hesiod tells it interrupts the decline, albeit briefly. ${ }^{17}$ His account of this era reflects a nostalgia typical of treatments of the Greek past—but, as discussed below, its very ability to interrupt decline may suggest hope for further change in the audience's future.

Despite these important themes, Hesiod's paradigm does more than provide a temporal framework. Through the successive generations Hesiod simultaneously supplies a multi-layered explanation of the present world, both its cosmology and its vices. Members of the golden generation continue in the world, though hidden, as guardians overseeing human interactions. The silver ones remain blessed from a residence under the earth. The bronze are left in chilly Hades. Meanwhile the heroes enjoy an island utopia which is likewise portrayed as continuing to exist at the edges of the ocean as Hesiod and his audience endure the iron generation. There is a sense in which each of the earlier stages all explain some aspect of the current cosmology, in a manner unlike the paradigm in Danielic versions discussed below. ${ }^{18}$ Hesiod's account transects the temporal framework with a synchronic, spatial claim.

14 The war of the heroes may be presented more positively than the violence of the bronze generation because it is not violence among members of the same group, but a kind of violence that is presented as an outworking of bravery, as heroes defend the good from some "other."

15 See below for discussion of Virgil's interaction with this theme.

16 Momigliano discusses ancient writers including Seneca and Florus, who represent the periods of history with portions of the human lifecycle, thus suggesting the process of transition between empires is natural (Arnaldo Momigliano, "The Origins of Universal History," in The Poet and the Historian: Essays in Literary and Historical Biblical Criticism, ed. Richard Elliott Friedman, Hss [Chico, CA: Scholars Press, 1983], 136).

17 Westra and Nikolic frame the comparisons between generations both in absolute terms (gold and iron are the best and worst) and relative terms (the heroes generation interrupts the decline, being relatively better than either bronze or iron) (Westra and Nikolic, "The Logic," 315-16).

18 The statue of Daniel 2 may imply some continuing function of past empires, which are described from the head down and remain in the same object until the statue's destruction; 
The description of each generation also builds up a picture of Hesiod's concerns about the present time. Indeed, it neatly complements the Prometheus and Pandora story. Brown suggests that the historical structuring of the paradigm enables Hesiod to offer "an aetiology of vice." ${ }^{19}$ But the particular behaviors described are also important. He argues:

Put together, the past bad races account for the origin of the vices which Hesiod considers to be most prevalent among his contemporaries, and to present the greatest threat to their wellbeing: the idleness, violence, and unrighteousness demonstrated by the silver and bronze races are all forms of hybris. The iron race combine all these with a few new forms of degeneracy—their wrong-doing (perjury, swindling and the like) is characterized by a certain increased sophistication and emphasis on deceit $(220-24 ; 250-51 ; 258-69 ; 322-34) .{ }^{20}$

In these various ways, I suggest, Hesiod returns the focus to the present time. He gives his own account of what is wrong now, set within a narrative of how it has emerged in his society and colored by nostalgia for a past supposedly immune from such disaster. Meanwhile, the diachronic elements raise the question: what should the audience (represented by Perses) expect will happen next?

The vôv and Future in the Context of Hesiod's

Five-Generation Paradigm

Hesiod unambiguously states the position of the present time within his schema. Several of the texts discussed below engage in a kind of temporal play, supplying coded information for privileged readers to identify the present time. By contrast, Hesiod simply tells the reader the temporal information: the heroes were the generation directly before his own and "now"- the time of the reader-is the generation of iron.

The position of the present time in Hesiod's account, though explicitly identified, nonetheless contributes to a point of contention in scholarly discussion. There is some disagreement about how many periods there are in Hesiod's paradigm. This might seem rather surprising given each generation is actually

this is still different from noting the ongoing existence of a group in a kind of mythic cosmology in Hesiod's poem.

19 Brown, "From the Golden Age," 388. For Westra and Nikolic, Hesiod's generations constitute a "more abstract, theoretical and complex, but strictly logical exploration of the problem of good and evil as an explanation of the human condition" (Westra and Nikolic, "The Logic," 318).

Brown, "From the Golden Age," 389. 
numbered (109, 127, 143, 157, 174), including when Hesiod bemoans that he has to live among the "fifth men ( $\dot{\nu} \delta \rho \dot{\alpha} \sigma \tau)$ " for "now" the generation is of iron (17476). There is no enumeration of a "sixth" ү'́vos. However, many interpreters argue for six, dividing the iron generation into an initial period in which there is a mix of good things with bad (179), and a second iron generation during which there is no longer any good and everything will collapse into the bleak, final picture Hesiod offers. ${ }^{21}$

However, I suggest that Hesiod's placement of the present time confirms his enumeration of the five generations and clarifies no sixth, additional generation within the description of the iron generation is required. Hesiod lives within the iron generation, a period which spans both before and after the moment of his writing, not the transition point between two generations. ${ }^{22}$ That the description of iron is longer is consistent with other texts which spend longer detailing the period of the writer's time. ${ }^{23}$ The prophetic, future tense elements in the description of the iron generation are simply a further description of the current period as it continues. ${ }^{24}$

Although sharing the same period, in another sense Hesiod distances himself from the iron generation and its pitfalls. As noted above, by providing the larger framework of generations, Hesiod describes the beginning and escalation of the kinds of vices and impiety he wishes to criticize in his own time. These are not traits he identifies in himself. But does Hesiod see any way out of the bleak picture with which he concludes?

There are two key ways in which readers have found hints of a more positive future in Hesiod's text, inspired by either: (1) the generation of heroes, or (2) the golden generation. When the heroes suddenly interrupt the trajectory

21 Westra and Nikolic argue that six generations allows for a parallel structure between the first "mythological" three generations, and a remaining three "historical" generationsthe latter beginning with the heroes (Westra and Nikolic, "The Logic," 317). Although it is helpful to highlight parallels, for instance, between the gold and heroes generations, this does not require a sixth generation.

22 Hesiod's wish to have been born before or after the current generation (175), discussed further below, likewise does not support a sixth generation within the description of iron. $\mathrm{He}$ is not longing to have been born within the time of the further decline prophesied here, but something beyond it.

23 The cumulative effect of the problems which build up over time also results in more elements requiring comment by the fifth generation.

24 Development continues over the course of some other generations, for instance the Bronze generation becomes increasingly worse until they eventually bring about one another's destruction. The iron generation's continued decline likewise does not require a further generation as explanation. 
of decline, they show that decline, once begun, is "not always irreversible."25 Brown suggests this may indicate to Hesiod's audience that change remains possible. This assurance from the past could inform the future, ${ }^{26}$ though the further decline is also couched as a form of prophecy. ${ }^{27}$ It predicts a grim collapse, when humans will be abandoned by those who return to Olympus. Jenny Strauss Clay argues that Hesiod's purpose is to exhort his reader, through Perses, to overcome the vice and impiety that has caused the decline to alter this future. ${ }^{28}$ This may be a source of hope.

Alternatively, the golden generation may offer a solution. Brown considers the golden generation, particularly through its association with the gods, to be an unattainable ideal-but one which nonetheless has "the capacity to inspire. ${ }^{29}$ Such inspiration could also be a part of overcoming the vice and impiety which is prophesied to continue the decline. Or the larger framework may suggest a cyclical return to a golden generation. When identifying the present time with the generation of iron, Hesiod says he wishes he "could have either died first or been born afterward!" (175), implying that he imagines a further period after his own. ${ }^{30}$ This suggests to some interpreters that Hesiod has taken the tradition of four declining successive periods and transformed it into a cyclic model, in which a return to a golden age should be anticipated after the foretold demise of the iron generation. ${ }^{31}$

25 Brown, "From the Golden Age," 396.

26 This suggests an interesting convergence with the work done by Stuckenbruck on Jewish and early Christian texts. Stuckenbruck observes important similarities in the ways these texts structure time, particularly with regard to the way past events provide assurance about the future events still anticipated. See Loren T. Stuckenbruck, "How Much Evil Does the Christ Event Solve? Jesus and Paul in Relation to Jewish 'Apocalyptic' Thought," in Evil in Second Temple Judaism and Early Christianity, ed. Chris Keith and Loren T. Stuckenbruck, wUNT 2/417 (Tübingen: Mohr Siebeck, 2016), 142-68, esp. 161, 165. West, Hesiod: Works and Days, 174.

28 Clay, Hesiod's Cosmos, 33-34.

29 Brown, "From the Golden Age," 397. Of course, it is one thing to convince a reader that "nothing is better than a quiet agricultural existence" and the human "ideal state does not involve fighting or sailing," as Brown suggests the golden generation's model may do ("From the Golden Age," 397). It is another thing to give the reader the material or other resources required to overcome the struggle Hesiod identifies within present circumstances.

$30 \quad$ See Westra and Nikolic, "The Logic," 317.

31 Westra and Nikolic, "The Logic," 319. There are some less convincing, pseudo-scientific elements to Westra and Nikolic's argument, for instance as they seek to use trigonometric functions to graph the cyclical pattern of rise and decline across Hesiod's generations ("The Logic," 319-22). 
A reading which finds hope for arresting the decline through a further temporal rotation back to a golden generation, though explaining Hesiod's cryptic comment at 175, might not account for all features of his text, such as its nontemporal elements. Alternatively, if the heroes show that decline is not inevitable, the prophecy of the final part of the iron generation may be recast as an authoritative warning for his audience to change their ways. Whether or not these options provide a way to reverse decline, the ambiguity remains, with the possibility of reading different futures into the paradigm. As seen below, it seems that some of Hesiod's ancient readers, at least, exploited this ambiguity.

\subsection{Recalibrations in Augustan Literature}

Themes from Hesiod's myth of generations are taken in various different directions by later writers. Helen Van Noorden notes receptions of Hesiod's generations in, among other sources, Plato, Aratus's Phaenomena, and Horace's works. ${ }^{32}$ Here I focus on different adaptations in the works of two Latin writers from the Augustan period: Virgil and Ovid.

\subsubsection{Reimagining the Golden Age in Virgil}

The concept of a golden age took on a life of its own "out of Hesiod's idyllic image of a golden race ruled by Cronos," ${ }^{33}$ and in multiple works Virgil engages with the golden age under Saturn, the Roman god identified with Cronos. In fact, this theme is often used to track development in Virgil's writing. ${ }^{34}$ Eclogae 4.4-10 gives a description of a golden age which has already been realized in the birth of a child. ${ }^{35}$ The era is characterized by traits associated with life under Saturn, such as ease, blessing, and fertility. In the Georgics, Virgil introduces ideas about Jupiter imposing beneficial struggle (Georg. 1.121-59). ${ }^{36}$ By the time of the Aeneid, Saturn's time of blessing is a thing only of the past. King Evander, Aeneas, and his son wander through fields discussing the "golden

32 Helen Van Noorden, Playing Hesiod: The "Myth of the Races" in Classical Antiquity, ccs (Cambridge: Cambridge University Press, 2014), 174-96, 205-7. Brown ("From the Golden Age") focuses particularly on how the golden age is taken up in other literature.

33 Van Noorden, Playing Hesiod, 2.

34 Elen Theodorakopoulos, "Closure: The Book of Virgil," in The Cambridge Companion to Virgil, ed. Charles Martindale (Cambridge: Cambridge University Press, 1997), 157.

35 The prophetic style of Eclogae 4 prompted its use for divination, and some ancient Christian interpretation associated the birth of the child that inaugurates the golden age with Jesus. Slater identifies here a reference to expectations of a child for Octavia and Mark Antony (D. A. Slater, "Was the Fourth Eclogue Written to Celebrate the Marriage of Octavia to Mark Antony? A Literary Parallel," CR 26 [1912]: 114-19; Likewise, see Fairclough and Gould in the LCL Virgil, 1:2).

36 Van Noorden, Playing Hesiod, 11. 
ages men tell of" (8.324-35) under Saturn's reign, like a tour of an ancient site and past civilization. The passage evokes nostalgia about such a life of bliss and ease, but the time is definitely long gone, without any sense of return. Rather, it is a reimagined golden age underJupiter which is the real focus in the Aeneid. ${ }^{37}$

Virgil's twelve-book Latin epic, the Aeneid (written from the battle of Actium in 30-31 $\mathrm{BCE}$ until his death in $19 \mathrm{BCE}$ ) plays with time in numerous ways. ${ }^{38}$ But the primary way is by setting his story about Roman empire in the past world of Aeneas. A series of prophecies in Books 1, 6, and 8 are set out as vaticinia ex eventu-that is, the prophecies describe events which are in the future from the perspective of the text (and the time of Aeneas), but the historical past from the perspective of its readers. These "prophecies" enable Virgil not only to interpret the significance of the "future" events which are described, but to assert the endpoint to which they lead: imperium sine fine (1.279). Indeed, the "future" rule which Jupiter discloses to Venus (Aeneas's goddess mother) in Book 1 will be brought about by "the Trojan Caesar" descended from the "great Iulius" $(286,288)$. The reader knows who this is and that his time is now.

Despite Virgil's emphasis on the historical moment under Augustus, Karl Galinsky rightly notes the significance that he has written an "Aeneid" and not an "Augusteid."39 That is, it is important to the unfolding epic that Virgil uses the past stories of Aeneas's struggle to frame the current experience of Rome. The struggle does not simply undermine the text's Augustan triumphalism, however, as some "pessimistic" readers have claimed. ${ }^{40}$ Rather, I suggest,

37 Virgil follows the pattern also seen in Hesiod's poem, where the first, golden generation is ruled by Cronos and later generations by Cronos's son, Zeus. In the Aeneid, the earlier golden age was ruled by Saturn, while the later reimagined golden age is ruled by his son, Jupiter. The reason labor emerges is starkly different in Virgil's and Hesiod's portraits. See Karl Galinsky, Augustan Culture: An Interpretive Introduction (Princeton: Princeton University Press, 1996), 93-97, 121-25.

38 For example, with parallels through allusions to literary forerunners, especially Homer (with the first six books offering a reinterpreted Odyssey, and the last six the Iliad). See David Quint, "Repetition and Ideology in the Aeneid," MDTC 23 (1989): 9-54, esp. 9.

39 Galinsky, Augustan Culture, 125.

40 These "pessimistic" readings identify a reluctance to affirm empire in the ambiguities and hesitations of Virgil's text. Galinsky frames this as a response to the post-war environment in the second half of the twentieth century (Galinsky, Augustan Culture, 3-9). See also S. J. Harrison, "Some Views of the Aeneid in the Twentieth Century," in Oxford Readings in Vergil's Aeneid, ed. S. J. Harrison (Oxford: Oxford University Press, 1990), 1-20; and Stefan Krauter, "Vergils Evangelium und das lukanische Epos? Überlegungen zu Gattung und Theologie des lukanischen Doppelwerkes," in Die Apostelgeschichte im Kontext antiker und frühchristlicher Historiographie, ed. Jörg Frey, Clare K. Rothschild, and Jens Schröter, BZNW 162 (Berlin: Walter de Gruyter, 2009), 240-42. 
Virgil's playing with time is what enables both the struggle, and the ultimately triumphalist portrait of Augustan Rome, to coexist. Ambiguity and struggle characterize the events of Aeneas, and the wars the readers know have taken place since his time, but these are all in the past for the reader.

The historical review in Aen. 6.752-892 confirms that the reader's present time is part of a reinterpreted golden age. Here Aeneas takes a journey to the underworld, where he views a parade of historical characters with a commentary supplied by his father, Anchises. Again the scene couches characters and events in a vaticinium ex eventu. This creates certain ironies in the text. Towns which (the reader knows) will become insignificant and disreputable characters are mentioned, while significant events are not mentioned. Jumping over key moments in Roman history, Virgil shifts suddenly to Augustus. ${ }^{41}$ The words of Anchises cut through the temporal play to resound emphatically for the reader: "Turn hither now ... Here is Caesar!" (6.788-89). The description goes on, "this in truth is he whom you so often hear promised you, Augustus Caesar, son of a god, who will again establish a golden age (aurea condet saecula) in Latium amid fields once ruled by Saturn" (791-94) ${ }^{42}$ Despite the ironic elements, even skeptical interpreters recognize that Augustan Rome is what is being celebrated in this passage. ${ }^{43}$ The importance of this moment in Virgil's epic is confirmed by the similarly themed historical reviews in Aen. 1.262-304 and $8.624-728 .{ }^{44}$

The Aeneid is set in a time of the heroes and demigods. It is not the time of the reader. And indeed the reader knows there is a considerable chronological gap between these times and their own. Is this intervening period to be taken as a kind of iron age, full of the struggles of Punic Wars and civil war? Virgil does not say, and he likewise does not set out the other ages in Hesiod's framework. But when he portrays a return to a golden age, as he writes the Aeneid late in his life, he no longer suggests a purely circular return to life

41 D. C. Feeney, "History and Revelation in Vergil's Underworld," PCPS 32 (1986): 1-24, esp. 5, 7.

42 The LCL translation by Fairclough and Gould renders the plural "golden ages" in Latin singular in English.

43 Feeney, "History and Revelation," $15^{-16 .}$

44 Philip Hardie, Virgil's Aeneid: Cosmos and Imperium (Oxford: Clarendon, 1986), 339, 362. Even O'Hara, who argues that prophecy elsewhere in the Aeneid is ambiguous and untrustworthy, suggests readers are to trust the ekphrasis of Aeneas's shield in Book 8, because it removes ambiguity caused by characters' misunderstandings- here the prophecy comes directly from Vulcan to the reader (James J. O'Hara, Death and the Optimistic Prophecy in Vergil's Aeneid [Princeton: Princeton University Press, 1990], 173). I would also note, contra O'Hara, that the fact that this prophecy is in keeping with the others across the epic challenges the notion of untrustworthy prophecy in the Aenied, even if characters sometimes fail to understand the prophecies. 
under Saturn, but a revised age under Jupiter. This golden age is hard won. It is perhaps exemplified by the ending of the epic, in which Aeneas hesitates, but then kills his rival Turnus, and through bloodshed figuratively founds Rome (12.939-53). There is much still to unfold from that literary moment until the historical time of the reader. But the reader knows these intervening things have since taken place - "Now!" is the time of Caesar Augustus (6.788), and the imperium sine fine Jupiter foretold he would bring about (1.279).

Thus, Virgil's is a very different picture from the bleak moment with which Hesiod concludes his myth of generations, deep within the vice and impiety of the iron generation and supplying only ambiguous hints about whether decline is inevitable, or some further period "after" this generation may yet appear. By contrast, Ovid takes pessimism to new levels, while still perhaps responding to the type of triumphalism found in Virgil.

\subsubsection{Ironic Succession in Ovid}

Ovid also writes during the Augustan period, and in his fifteen-book Latin epic, the Metamorphoses, draws on the four ages of gold, silver, bronze, and iron. ${ }^{45}$ His model does not incorporate the heroes generation like Hesiod, and nor does he identify his own present time within any particular period in the scheme.

In Metam. 1.89-15o, Ovid uses the paradigm to set out primeval periods which are all over and done with before the bulk of his story. Again the four periods explain aspects of the human condition. They set out decline over successive periods. In the age of gold under Saturn, laws are not required but humans live in peace, accessing the land's fecund provisions without need for any labor in a constant spring-time. But with the silver age-again, worse than the golden age-Jupiter's reign begins. Here seasons are introduced and the people must find housing and farm for food. With the bronze age comes cruelty and hasty recourse to violence, but iron is the worst age which now adds impiety to the list of grievances. The result is bloodshed and misuse of the earth's resources, with reference also to a tradition about giants. ${ }^{46}$ The decline ultimately prompts the gods, called together by Jupiter, to bring all of the humans to an end with a flood, which draws the iron age to a close (1.177-347). These antediluvian stories also reflect a different involvement of the gods in human life. From the flood onwards the gods are conspicuously absent or mentioned primarily for their petty conduct (cf. 1.166, $588-600)$.

45 For a more detailed discussion of the ways that Ovid draws on and re-presents Hesiod, see Van Noorden, Playing Hesiod, 216-6o.

46 See discussion of this merged tradition in Van Noorden, Playing Hesiod, 220, 226-27. 
Ovid inverts many of the themes found in Virgil's Aeneid. ${ }^{47}$ The gods do not oversee things, and nor do the unfolding events lead to meaning for Ovid's audience. The four ages are all mentioned, but they are emphatically in the past; there is no sense that they might be reclaimed or reimagined. The decline does not end with the iron generation, but the epic's conclusion approaches further nihilism. The ending refers obliquely to the apotheosis of Augustus. In 15.870, Ovid states that Augustus will listen to prayers from heaven when he dies. But the reference to Augustus supports Ovid's irony. An epilogue gives the last laugh to the author himself: he alone is the one who will live on, through his text (15.871-79). Julia Dyson Hejduk notes that Ovid himself is thus presented as the unique "mortal whose triumph over the wrath of Jupiter, and over death itself, rises above the pettiness of Olympian squabbles." 48 Only Ovid's notoriety will endure.

As Hesiod uses his five-generation paradigm to say something about his own time, Virgil and Ovid each in their own ways draw on these themes to make claims about theirs. For all their differences, Virgil and Ovid both portray the present somewhat statically, with no apparent sense that current circumstances will change. By contrast, the kingdom paradigm as it appears in Daniel 2 and 7 , and texts which draw on it, is structured around claims that the present lies on the cusp of a decisive transition.

\section{3}

\section{Five Kingdoms in the Danielic Tradition}

\subsection{The Five Kingdoms in Daniel's Paradigm}

Other essays in this volume have already explored the formation and development of kingdom paradigms in Daniel 2 and 7, so I will not detail that background here. The main point of interest for this essay lies in the way in which the Danielic paradigm structures time in order to make a claim about the present time, and how this is then recalibrated by readers of Daniel—in particular, the writer of the Epistle of Barnabas.

The traditions behind Daniel's paradigm, as with Hesiod's sources discussed above, are difficult both to identify and to date. Most interpreters suggest Daniel has drawn on Persian traditions, and note the similarities in particular

47 See Julia Dyson Hejduk, "Ovid and Religion," in A Companion to Ovid, ed. Peter E. Knox, BCAW (Chichester: Wiley-Blackwell, 2009), 45-58.

48 Hejduk, "Ovid and Religion," 52. See also E. J. Kenney, "The Metamorphoses: A Poet's Poem," in A Companion to Ovid, ed. Peter E. Knox, BCAW (Chichester: Wiley-Blackwell, 2009), 140-53, esp. 144. 
with an account of a tree with branches of different metals (the fourth comprised of a mix of steel and iron) which is described to Zoroaster in the Bahman Yasht. ${ }^{49}$ Despite the earlier dating of Hesiod's text, given the likely ancient Near Eastern origin of the myth, John Collins suggests the best (though tentative) explanation is that both Hesiod and Daniel drew on an earlier common tradition. Similarly, he suggests the relationship between Persian texts such as the Bahman Yasht and Daniel's statue is also best understood as reliance on a common source. ${ }^{50}$

As in the myth of generations in Hesiod, Daniel's schema also has five kingdoms, despite the tendency to refer to the Danielic tradition as a four kingdom paradigm. For both Hesiod and Daniel, the present time is situated in the lowest period of the schema, the time of iron (and clay in Daniel 2, or of the worst beast in Daniel 7). But, whereas in Hesiod this is the fifth kingdom, in Daniel it is the fourth. It is only the anticipated fifth kingdom - a final, unending divine reign - that inverts the decline which has led up to the present in Daniel. ${ }^{51}$ Both Daniel 2 and 7 are presented in the form of vaticinia ex eventu. Daniel's interpretation of Nebuchadnezzar's dream describes Nebuchadnezzar's reign as the gold kingdom, and Daniel's vision of strange beasts is set in the first year of King Belshazzar of Babylon (Dan 7:1). But the details of the fourth kingdom in each case enable the audience to identify the actions of Antiochus IV and their own time as this period. One of the characteristic features of this type of "prophecy," of course, is to establish credibility through correctly "predicting" the events which are already in the past from the perspective of the reader, in order to underscore the certainty of the events still to come. In doing so, Daniel 2 and 7 both allow the reader to identify the present with the nadir of the process, which assures that the vindication of the divine action to install the final regime is imminent.

The devastation in Daniel 7 comes from the violent acts of the strange beasts, which symbolize particular regimes. As discussed above, Hesiod does not identify with the vices of the iron generation. But his didactic text suggests a moralizing purpose; perhaps the reader may avert the predicted decline by altering the behavior which has become endemic during this generation. In Daniel, the writer likewise does not identify with the destructive animals, but neither does he exhort a change in the behavior of those they represent. Rather, the focus lies in the decisive divine action to bring an end to the kingdom.

49 See discussion in Collins, Daniel, 163.

5 See $n .9$ above.

51 This is unlike the positive era of the heroes, which immediately precedes the destructive present generation for Hesiod. 
In this way, the present is central to how time is structured in this fivekingdom paradigm: it is situated immediately prior to the events which are predicted to bring an end not only to the current destructive empire, but the whole pattern of successive destructive regimes. The powerful image is taken up by many readers and recalibrated for new times. Such adjustments already feature elsewhere in Daniel. The vision in Daniel 9 explicitly "corrects" Jeremiah's prophecy about the number of years until Babylon's punishment (Dan 9:2, 24-27; cf. Jer 25:11-12), allowing for both the prophecy to remain authoritative and the implementation to remain imminent. ${ }^{52}$ This is the same reasoning at work in the later recalibrations of Daniel's five kingdom paradigm, whether by writers of other apocalypses such as 4 Ezra (12:11-12) and 2 Baruch (35-40), or Josephus in his affirmation of Daniel's prophetic prowess (Ant. 10.277-80). ${ }^{53}$ For each of these other re-interpretations, the penultimate kingdom has become Rome.

By employing this symbolic machinery, the later writers are able to draw on Daniel's authoritative claims, even in texts of different genres, to interpret the suffering of the present time and to point to an imminent intervention by the divine to set things right. This tradition is also taken up by the writer of the Epistle of Barnabas.

\subsection{Recalibration in the Epistle of Barnabas}

The Epistle of Barnabas is a Christian Greek text, written after the destruction of Jerusalem (cf. 16:3-4) and most likely nearer to (but not after) the time of the second revolt. ${ }^{54}$ Despite the title attributed to it, there is consensus that it was not written by the companion of Paul. Its form as a letter is also more

$5^{2}$ See Laura Bizzarro, "The 'Meaning of History' in the Fifth Vision of 4 Ezra," in Interpreting 4 Ezra and 2 Baruch:International Studies, ed. Gabriele Boccaccini and Jason M. Zurawski, LSTS 87 (London: Bloomsbury, 2014), 35-37.

53 Josephus's Antiquities, 4 Ezra, and 2 Baruch are all written around the turn of the first century CE. For discussion of the use of Daniel's paradigm in later Jewish texts, see Philip R. Davies, "Daniel in the Lion's Den," in Images of Empire, ed. Loveday Alexander, JSOTSup 122 (Sheffield: Jsot Press, 1991), 160-78.

54 See discussions in James Carleton Paget, The Epistle of Barnabas: Outlook and Background, wUnT 2/64 (Tübingen: Mohr Siebeck, 1994), 9-30; and Reidar Hvalvik, The Struggle for Scripture and Covenant: The Purpose of the Epistle of Barnabas and Jewish-Christian Competition in the Second Century, wUnT 2/82 (Tübingen: Mohr Siebeck, 1996), 17-34. Each offers slightly different views, but they agree on an early second-century date, for different reasons, suggesting that the date cannot be later than approximately $130 \mathrm{CE}$. Considerable discussion about the dating of the text has been based on the interpretation of Barn. 16:3-4 (in relation to expectations that the temple will be rebuilt) and the prophecy in Barn. 4:3-5, to which I refer below. 
contentious than the title implies, despite its epistolary frame in chapters 1 and $21 .{ }^{55}$ The bulk of the text (ch. 1-17) is comprised of a series of explanations about the right interpretation of the law, relating to sacrifices, circumcision, food laws, sabbath, etc. ${ }^{56}$ The later sections (ch. 18-20) offer a reflection on the two-ways tradition, with instruction about living on the path of light (ch. 19) and the features of the path of darkness (ch. 20). ${ }^{57}$ Barnabas seems to have enjoyed a mixed status. It is rejected by Eusebius, ${ }^{58}$ but the fact that it is found alongside The Shepherd of Hermas with the texts that would become canonical in codex Sinaiticus illustrates that it was taken as authoritative in at least some circles. ${ }^{59}$

Barnabas is most renowned for its polemical character. Through a contrast between "us" and "Israel," it argues that groups which practice the law have utterly misunderstood the scriptures. In particular it refutes literal interpretations of the law as they relate to key Jewish practices and advocates instead for the authenticity of an allegorical reading. The text is thus an important example of identity formation through distinguishing one's own group from another in early Christianity. James Carleton Paget argues convincingly that these polemics arise from direct knowledge of Jewish groups and practices. ${ }^{60}$

It is, therefore, an interesting feature of a text which presents Jewish tradition and its interpretation of the law in such a negative way that it nonetheless continues to draw on Jewish scripture to substantiate its point. This is not the

55 Even those who do not consider Barnabas's genre to be "letter" still note the epistolary frame in chapters 1 and 21, frequently suggesting genres such as theological treatise for the material of the intervening chapters. Hvalvik, by contrast, argues that the work is a letter, and that the material included is best explained as having been reworked from lectures or sermons (Hvalvik, The Struggle, 81). After outlining some other arguments, Paget concludes via a comparison with Ignatius's letters, that "Such a mixture of features finds parallels in Barn, and should warn us against too hastily adopting a non-epistolary understanding of that document's form" (Paget, The Epistle, 45).

$5^{6}$ See discussion in Paget, The Epistle, 51-52. Paget also points out that the material criticizing ritual law appears at important points in the literary structure of the first major section of the text, in the beginning (ch. 2-3), middle (ch. 9-10), and end (ch. 15-16).

57 Ehrman argues that the obvious common themes with the Didache here are best explained by a common source rather than direct dependence in either direction (Bart D. Ehrman, The Apostolic Fathers, LCL 25 [Cambridge, MA: Harvard University Press, 2003], 2:5).

$5^{8}$ Barnabas is listed among the illegitimate or spurious (vó $\theta$ os) works which should not be counted among the NT (Hist. eccl. 3.25.4). For Eusebius this is a separate category from both those which should clearly be included and those which are disputed.

59 Clement of Alexandria is the earliest source to cite Barnabas as authoritative (see Ehrman, The Apostolic Fathers, 2:3).

6o Paget, The Epistle, 52. There is some disagreement in earlier studies over whether the interlocutors Barnabas has in mind are Jesus-believers who continue to practice and advocate for the law, or Jews who are not a part of the Jesus movement. 
kind of attitude, associated especially with Marcion, in which all earlier claims to revelation are disregarded, but an appropriation of earlier texts as authoritative revelation that has been consistently misinterpreted since it was first received (4:7-8) and now can be set right by the author of Barnabas. The text thus claims this heritage as its own. ${ }^{61}$ This is also a feature of how the writer presents Daniel's prophecy.

\subsubsection{The Five Kingdom Paradigm in Barnabas 4}

In Barnabas 4, the author applies Daniel 7 to his own setting as an authoritative prophecy, in order to claim that the present time lies on the cusp of the final events. Barnabas 4:3-5 features frequently in studies of Barnabas, as one of two passages routinely cited in debates about the text's compositional date. But the passage is not generally analyzed for what it communicates about the writer's understanding of the structuring of time. ${ }^{62}$ I suggest that this is an important feature of how Daniel's prophecy functions in Barnabas 4, and that it in turn illuminates other features of the text as a whole.

After the epistolary opening and introduction (ch.1), Barnabas discusses sacrifices (ch. 2) and fasting (ch. 3). The final verse of chapter 3 reflects back on the interpretation of fasting through the lens of Isaiah 58 alluded to in Barn. 3:1-5: "And so he revealed all things to us in advance, that we not be dashed against their law as newcomers" (3:6). ${ }^{63}$ Claims about special insight into the true meaning of the scriptures are an important feature across Barnabas (1:7; 5:3; 6:9-10; 9:9). ${ }^{64}$ Here the ending of chapter 3 also sets up the writer's claims to true knowledge of the meaning of Daniel's earlier prophecy in the section which follows $(3: 3-5)$.

Warning and a sense of eschatological seriousness continue throughout Barnabas 4, and it is in this context that the writer cites Daniel 7. The prophecy allows the writer to set the present time within the context of a wider paradigm, counting time towards the present. After a reference to Enoch in 4:3

61 Paget describes this as "radically conservative" (Paget, The Epistle, 52).

62 Ferguson is a helpful exception, treating Barnabas 4 within his broader discussion of possible millenarianism in Barnabas (Everett Ferguson, "Was Barnabas a Chiliast? An Example of Hellenistic Number Symbolism in Barnabas and Clement of Alexandria," in Greeks, Romans, and Christians: Essays in Honor of Abraham J. Malherbe, ed. Balch, Ferguson, and Meeks [Minneapolis: Fortress, 199o], 157-67). The importance of eschatology in Barnabas is also confirmed by the discussion of the thousand-year sabbath as Barnabas's non-literal interpretation of laws about sabbath in ch. 15 .

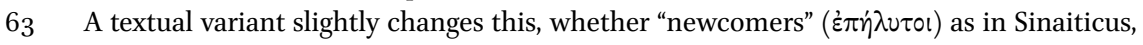

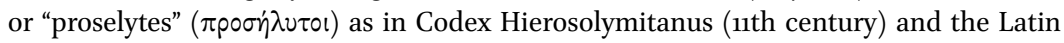
translation.

64 See discussion in Ehrman, The Apostolic Fathers, 2:4. 
(which is not clear), ${ }^{65}$ the writer includes two citations of Daniel 7 , though the first is attributed to "the prophet" and it is not until the second that attribution to Daniel is made. The first comes from the explanation of the ten horns in Dan 7:24: "Ten kingdoms will rule the earth and a small king will rise up afterwards; he will humble three of the kings at one time" (4:4). ${ }^{66}$ The second is from the description of the vision itself, in Dan 7:8, and sets the prophecy within the five-kingdom paradigm: "I saw the fourth beast, wicked and strong, and worse than all the beasts of the seas, and I saw how ten horns rose up from him, and from them a small horn as an offshoot; and I saw how he humbled three of the great horns at one time" (4:5).

As in other uses of the paradigm discussed above, Barnabas shows the decline of the fourth kingdom as "worse" than all the previous and, as in Daniel, it supplies the further details which might enable the audience to identify their own time. There are minimal changes to the details in Daniel, though the text does not follow the exact wording of any known Greek version. ${ }^{67}$ This causes difficulties for contemporary scholars' attempts to date the text by aligning the "little horn" with historical events. ${ }^{68}$ However, it seems, the writer does not

65 It is not clear whether the reference to Enoch relates to the preceding statement about the final stumbling block, or acts as an introductory formula for the verse which follows about cutting short the time. Rhodes notes that, either way, scholars have been unable to agree on any particular Enochic passage to explain the reference (James N. Rhodes, The Epistle of Barnabas and the Deuteronomic Tradition: Polemics, Paraenesis, and the Legacy of the Golden-Calf Incident, wUNT 2/188 [Tübingen: Mohr Siebeck, 2004], 47 n. 42).

66 Note the discussion of textual differences between "kings" or "kingdoms" here, and in manuscripts of Daniel 7, in Rhodes, The Epistle, 48. The difference between the vision and its explanation may also explain the different attributions to "the prophet" and to Daniel.

67 Paget, The Epistle, 10. The key differences lie in Barnabas's description of the little horn as an "offshoot" and the destruction of the three horns "at the same time" (Paget, The Epistle, 11).

68 See extensive discussion of options in Hvalvik, The Struggle, 27-32; Paget, The Epistle, 9-17; Rhodes, The Epistle, 47-52. The historical situation which seems closest to the description of both the number of horns and the simultaneous humbling of three is the time of Vespasian and the three emperors who each reigned in turn within the same year (69 CE, almost "at once"). However, most agree Vespasian's reign is too early for the writing. Hvalvik sidesteps the issue by claiming this is the historical situation to which the application of the prophecy referred in the text which Barnabas used as a source (Hvalvik, The Struggle, 26-28). Others note possible later constellations of emperors who might fit the three (e.g., leading to seeing Nerva as the "little horn" currently in power). And many theories exist for counting the ten or eleven horns, depending on whether the little horn, as an "offshoot", is to be counted also as one of the ten, or an eleventh. See discussion in Rhodes about reading the fourth beast positively from the perspective of the destruction of Jerusalem, with Barn. 16:3-4 as further support. Rhodes is rightly skeptical about such a radical divergence in use of Daniel 7 from other receptions of this 
expect any such difficulty for the reader, or he considers a formulaic statement sufficient to make them realize this is their time. Immediately following the

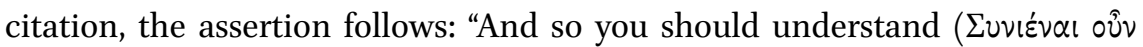
o $\varphi \varepsilon i \lambda \varepsilon \tau \varepsilon)$ " (v. 6). ${ }^{69}$ As the chapter moves immediately back into a didactic, hortatory mode, it suggests there is something important in this prophecy for the audience in their particular time.

\subsubsection{The vôv xalpós in the Context of the Five Kingdom Paradigm in Barnabas 4}

The application of Daniel in Barnabas 4 is part of a wider emphasis on the present time in the context of an eschatological framework. In 1:7, the writer asserts that earlier prophecy reveals both the past and the reader's present, as well as an insight into the future: "For through the prophets the Master has made known to us what has happened and what now is; and he has given us the first fruits of the taste of what is yet to be." The text goes on to emphasize the accuracy of prophecy which the readers can now see has been fulfilled in the past, before claiming further special insight which will enable the writer to reveal more that "will gladden your hearts in the present circumstances" (1:8).

Chapter 4 offers numerous references to the present time. It opens with exhortation about attending to the features of the present age with an eye to eschatological matters, leading to the assertion, "And we should hate the error

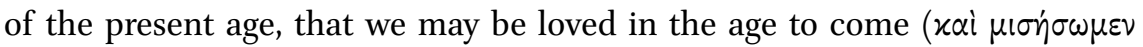

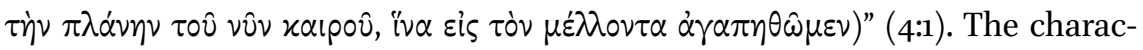
ter of the present time is dark; it is a time of lawlessness $(4: 1,9)$. But it is also set in relation to other eschatological events. Though the language might be more cryptic than Hesiod's explicit identification of the present time in his framework, the writer of Barnabas does situate his reader. Having already claimed a taste of the first fruits of the eschaton (1:7), just before introducing Daniel's prophecy in chapter 4 he asserts: "the final stumbling block ( $\tau \dot{0} \tau \varepsilon \dot{\lambda} \lambda \varepsilon 10 \mathrm{~V}$ $\sigma x \alpha \dot{\alpha} \delta \alpha \lambda \circ v)$ is at hand" (4:3). After citing Daniel, and offering a further warning related to what he claims is the mistaken interpretation of the law and Jewish claim to the covenant, he exhorts that:

text, given the brief reference and lack of further evidence of this reading in Barnabas 4 (Rhodes, The Epistle, 51).

69 There is a textual difficulty in 4:6b, which affects interpretations about the covenant and Jewish and Christian relations, but is less relevant to the questions central to the current essay. See the argument in Rhodes, The Epistle, 24-28. 
Therefore, we should pay close attention in the final days $(\Delta i \dot{o} \pi \rho 0 \sigma \varepsilon \chi \omega-$ $\mu \varepsilon \nu \dot{\varepsilon} \nu \tau \alpha \hat{\imath} \varsigma \dot{\varepsilon} \sigma \chi \alpha^{\prime} \tau \alpha \iota \zeta \dot{\eta} \mu \varepsilon \dot{p} \rho(\varsigma) .{ }^{70}$ For the entire time of our faith will be of no use to us if we do not stand in resistance, as is fitting for the children of God, both against this present lawless age and against the stumbling blocks that are yet to come, that the Black One not sneak in among us $(4: 9-10)$.

That the final stumbling block is "at hand" ("̈ $\gamma(x \varepsilon v)$ (4:3) and yet further stumbling blocks are yet to come (4:9) may suggest some incoherence. However, both verses indicate an eschatological consciousness and, whether the difficulties anticipated imminently are akin to messianic woes or simply the suffering of the fourth and "worse" kingdom (cf. 4:5), they remain precursors to the anticipated end. In 4:9 the reader is exhorted to resistance in both "this present lawless age" and "against the stumbling blocks to come" which perhaps suggests the stumbling blocks are expected as final events after the present moment. If they relate to the final stumbling block of $4: 3$ then it is clear that all of this involves a sense of urgency; not only is this final $\sigma x \alpha \dot{v} \delta \alpha \lambda$ ov already near, but the verse goes on to explain that because of this "the Master short-

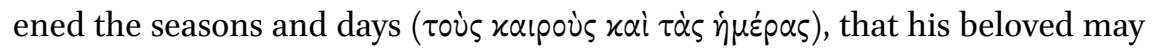
hurry and arrive at their inheritance" (4:3). ${ }^{71}$ The idea of divine oversight of historical progress, causing further acceleration towards the end, is found in apocalypses, such as 2 Bar 20:1-2. That this claim in Barnabas 4 introduces the prophecy from Daniel confirms its eschatological urgency.

Helpful readings of this text may, therefore, not require identification of a particular historical event as the final stumbling block, whether or not the writer had one in mind, but to recognize the eschatological character and emphasis on the nearness of the culmination from the perspective of the (difficult) present. Similarly this may be the best approach to the details about ten or eleven horns. James Rhodes rightly observes "apocalyptic 'code' is notoriously open to reinterpretation by later readers, whether ancient or modern; hence, even if we knew Barnabas's intention beyond doubt, there is no guarantee that his

70 In the LCL edition, Ehrman translates "here in the final days" (4:9), but the term for "here" is not in the Greek. Although it is possible to make a case that this is in keeping with the writer's eschatological outlook, it is not clear that he does believe he already lives among the last days.

71 Ehrman's LCL translation, modified for gender inclusive language. The xalpoi here could, of course, refer to temporal periods rather than seasons of the year, as is common in Jewish and early Christian literature, including Daniel 2 and 4. See Kylie Crabbe, Luke/ Acts and the End of History, BZNW 238 (Berlin: Walter de Gruyter, 2019), 118-23. 
reading of the text would not strike us as contrived."72 This is the case for many recalibrations of the paradigm as it is applied to new historical circumstances. This does not mean that the writer did not expect the audience to make some connection between current events and those in the paradigm as applied. The direct address in Barn. 4:6 suggests that is exactly what is expected, even if only through the generic phrasing.

After addressing the reader in this way, the writer moves from prophecy immediately into paraenesis, which contains plenty of polemic. As in the texts discussed above it is helpful to consider where the writer positions themselves (and the audience) in relation to the current, fourth kingdom. The terrible circumstances of the present time and its stumbling blocks, whatever historical analogue might be implied, are not caused by events with which the writer identifies, though they affect him. They are most likely identified with the actions of the empire itself. But the tone of eschatological seriousness lends severity to the consequences of choices that are made during this difficult time. The sins that are "piling up" are not in the first instance those of the Christian audience but the opposing groups described with anti-Jewish rhetoric. Nonetheless, the implied audience risks the consequences of such sin if they choose to claim the covenant is "both ours and theirs", thus aligning themselves with the accumulating sinfulness of the opposing groups.

By making use of the resources offered by the authoritative text, recalibrated for a new time, the writer emphasizes the eschatological tension in the present. Perhaps surprisingly, he does not cite the end of the paradigm and the divine reign, which dominates a large portion of the text in Daniel 7. The brief reference to only Daniel's "fourth beast" alongside the interpretation of ten kingdoms suggests that the reader was likely to be familiar with the rest of the paradigm, but Barnabas leaves that unmentioned. Emphasis remains on the present, but with enough hints about the future to confirm a larger framework in which the present is found. A conclusion that Barnabas primarily indicates a general sense of "soon" with this paradigm may seem to undermine the importance of his eschatological claims. However, I suggest it shows a key element of what the paradigm offers: an insight into the structuring of time. It supplies the dual sense of the need for change and the promise that this is imminent, recalibrated from the earlier tradition. This enables the authoritative text to support a constant anticipation that the end is imminent no matter how much time has come before, confirming the call to resistance and endurance $(4: 9-10)$. 
In each text discussed here, the paradigm of four (or five) kingdoms/generations facilitates something important in how the writer communicates the structuring of time. In particular, it enables the writer to say something about the present time by relating it to a wider pattern. The past periods provide the broader context, which can even be reduced to simply a reference to the "fourth" period with an explicit cross-reference to a source text while the other periods are presumed (Barn. 4:5; cf. 4 Ezra 12:11). For texts like Daniel and those which draw on it, having established this broader pattern, the key focus lies on the provisional character of the present time. Even as the present time is recalibrated for a new audience, the writer stresses the relationship between the (dire) present and the imminent end to be brought about by the fifth, divine empire.

Also in Hesiod, the present time offers a hint of provisionality. Here it arises through confidence sparked by the past - the generation of heroes shows that decline is not necessarily inevitable - and the ambiguity introduced by the cryptic comment about wishing to be born before or after the current time. ${ }^{73}$ This ambiguity queries what the reader should expect next. In Hesiod the present time is characterized by vice and impiety that Hesiod disdains. But whether some change in circumstance might be possible, as hinted, depends on whether the prophecy for the remainder of the iron age must inevitably unfold.

In each of these examples, the present time is identified with the low-point of the paradigm of successive periods. But some ancient writers who draw on Hesiod's myth of generations rework the present time differently. In a helpful study of politics and temporality in ancient texts, Collins argues that "apocalyptic dissenters" and "imperial propagandists" hold essentially the same understanding of the structure of history, but that they differ in how they situate the present time. ${ }^{74} \mathrm{He}$ contrasts those who portray the end of history as having been realized already in the present (a view which he terms "ideology") with those who continue to anticipate the end beyond current political structures ("utopia"), ${ }^{75}$ arguing that this distinction reflects the essential difference in how these groups structure time. The contrast similarly highlights an important

73 See n. 26 above on Stuckenbruck's argument about ways that past events provide assurance for the future in Jewish and Christian texts.

74 John J. Collins, "Temporality and Politics in Jewish Apocalyptic Literature," in Apocalyptic in History and Tradition, ed. Rowland and Barton, JSPSup 43 (Sheffield: Sheffield Academic, 2002), 42.

75 Collins uses Karl's Mannheim's distinction between "ideology" and "utopia" respectively to illustrate this distinction (Collins, "Temporality and Politics," 28). 
distinction in how the paradigm functions in texts which build on the ambiguity left at the conclusion of Hesiod's myth.

In Virgil's account of the present time, the end and goal of a golden age has already been achieved under Augustus. This is not only a reworking of Hesiod's paradigm away from the golden generation under Cronos to reimagining a golden age under Jupiter, but it also involves repositioning the present time. The present is not located in struggle (as in those texts which identify the present with an age of iron), and as a result, it is also not about any further anticipated change. It is static, like the "ideology" of Collins's model. Ovid's bleak picture is rather different; all the four ages are well in the past. But the present time is also static. It approaches nihilism, distancing the present from the mythological times represented by the four ages but offering no further meaning or hint of future change.

How each of these texts implies the reader ought to respond reflects further differences in their applications of the paradigm-from Hesiod's assessment of the current generation and its future (reworked into Virgil's confidence in imperial circumstances and Ovid's nihilistic trajectory), to Barnabas's adaptation of Daniel's quietism (manifest in awaiting divine action) into an exhortation to certain theological and ethical positions during this crucial time before the end. But, in each case, the present time is central to how they appropriate the paradigm. The four/five-period schema allows the writers to play with broad sweeps of time. But the pattern it offers is a way of addressing the present, constantly recalibrated, but always "now."

\section{Bibliography}

Bizzarro, Laura. "The 'Meaning of History' in the Fifth Vision of 4 Ezra." Pages $32-38$ in Interpreting 4 Ezra and 2 Baruch: International Studies. Edited by Gabriele Boccaccini and Jason M. Zurawski. LSTS 87. London: Bloomsbury, 2014.

Brown, A. S. "From the Golden Age to the Isles of the Blest." Mnemosyne 51 (1998): $385-410$.

Clay, Jenny Strauss. Hesiod's Cosmos. Cambridge: Cambridge University Press, 2003.

Collins, John J. A Commentary on the Book of Daniel. Hermeneia. Minneapolis: Fortress, 1993.

Collins, John J. “Temporality and Politics in Jewish Apocalyptic Literature." Pages 26-43 in Apocalyptic in History and Tradition. Edited by Christopher Rowland and John Barton. JSPSup 43. Sheffield: Sheffield Academic, 2002.

Crabbe, Kylie. Luke/Acts and the End of History. BzNW 238. Berlin: Walter de Gruyter, 2019 . 
Davies, Philip R. "Daniel in the Lion's Den." Pages 16o-78 in Images of Empire. Edited by Loveday Alexander. JSOTSup 122. Sheffield: Jsot Press, 1991.

Ehrman, Bart D., ed. and trans. The Apostolic Fathers, Volume II: Epistle of Barnabas. Papias and Quadratus. Epistle to Diognetus. The Shepherd of Hermas. LCL 25. Cambridge, MA: Harvard University Press, 2003.

Feeney, D. C. "History and Revelation in Vergil's Underworld." PCPS 32 (1986): 1-24.

Ferguson, Everett. "Was Barnabas a Chiliast? An Example of Hellenistic Number Symbolism in Barnabas and Clement of Alexandria." Pages 157-67 in Greeks, Romans, and Christians: Essays in Honor of Abraham J. Malherbe. Edited by David L. Balch, Everett Ferguson, and Wayne A. Meeks. Minneapolis: Fortress, 1990.

Galinsky, Karl. Augustan Culture: An Interpretive Introduction. Princeton: Princeton University Press, 1996.

Hardie, Philip. Virgil's Aeneid: Cosmos and Imperium. Oxford: Clarendon, 1986.

Harrison, S. J. "Some Views of the Aeneid in the Twentieth Century." Pages 1-20 in Oxford Readings in Vergil's Aeneid. Edited by S. J. Harrison. Oxford: Oxford University Press, 199o.

Hejduk, Julia Dyson. “Ovid and Religion.” Pages $45^{-5} 8$ in A Companion to Ovid. Edited by Peter E. Knox. BCAw. Chichester: Wiley-Blackwell, 2009.

Hesiod. Theogony, Works and Days, Testimonia. Edited and translated by Glenn W. Most. LCL 57. Cambridge, MA: Harvard University Press, 2018.

Hvalvik, Reidar. The Struggle for Scripture and Covenant: The Purpose of the Epistle of Barnabas and Jewish-Christian Competition in the Second Century. WUNT 2/82. Tübingen: Mohr Siebeck, 1996.

Kenney, E. J. “The Metamorphoses: A Poet's Poem." Pages 140-53 in A Companion to Ovid. Edited by Peter E. Knox. BCAw. Chichester: Wiley-Blackwell, 2009.

Krauter, Stefan. "Vergils Evangelium und das lukanische Epos? Überlegungen zu Gattung und Theologie des lukanischen Doppelwerkes." Pages 214-43 in Die Apostelgeschichte im Kontext antiker und frühchristlicher Historiographie. Edited by Jörg Frey, Clare K. Rothschild, and Jens Schröter. BZNW 162. Berlin: Walter de Gruyter, 2009.

Momigliano, Arnaldo. "The Origins of Universal History." Pages 133-48 in The Poet and the Historian: Essays in Literary and Historical Biblical Criticism. Edited by Richard Elliott Friedman. Hss. Chico, CA: Scholars Press, 1983.

O'Hara, James J. Death and the Optimistic Prophecy in Vergil's Aeneid. Princeton: Princeton University Press, 1990.

Ovid. Metamorphoses. 2 vols. Translated by Frank Justus Miller. Revised by G. P. Goold. LCL 42-43. Cambridge, MA: Harvard University Press, 1916.

Paget, James Carleton. The Epistle of Barnabas: Outlook and Background. WUNT 2/64. Tübingen: Mohr Siebeck, 1994.

Quint, David. "Repetition and Ideology in the Aeneid." MDTC 23 (1989): 9-54. 
Rhodes, James N. The Epistle of Barnabas and the Deuteronomic Tradition: Polemics, Paraenesis, and the Legacy of the Golden-CalfIncident. WUNT 2/188. Tübingen: Mohr Siebeck, 2004.

Slater, D. A. "Was the Fourth Eclogue Written to Celebrate the Marriage of Octavia to Mark Antony? A Literary Parallel." CR 26 (1912): 114-19.

Stuckenbruck, Loren T. "How Much Evil Does the Christ Event Solve? Jesus and Paul in Relation to Jewish 'Apocalyptic' Thought." Pages 142-68 in Evil in Second Temple Judaism and Early Christianity. Edited by Chris Keith and Loren T. Stuckenbruck. WUNT 2/417. Tübingen: Mohr Siebeck, 2016.

Theodorakopoulos, Elena. “Closure: The Book of Virgil." Pages 155-66 in The Cambridge Companion to Virgil. Edited by Charles Martindale. Cambridge: Cambridge University Press, 1997 .

Van Noorden, Helen. Playing Hesiod: The "Myth of the Races" in Classical Antiquity. ccs. Cambridge: Cambridge University Press, 2014.

Virgil. Aeneid. Translated by H. Rushton Fairclough. Revised by G. P. Goold. 2 vols. LCL 63-64. Cambridge, MA: Harvard University Press, 2000.

West, M. L. Hesiod: Works and Days. Oxford: Oxford University Press, 1978.

Westra, Haijo Jan and Nikolic, Milo. "The Logic of the Myth of the Ages in Hesiod's Works and Days." Mouseion 6.3 (2006): 313-22. 